\title{
EFFECTS OF GLYPHOSATE ON GERMINATION AND PHOTOSYNTHESIS IN Prosopis alba G.: A BIOCHEMICAL APPROACH
}

\section{EFEITOS DO GLIFOSATO NA GERMINAÇÃO E NA FOTOSSÍNTESE EM Prosopis alba G.: UMA ABORDAGEM BIOQUIIMICA}

\author{
Diego Ariel Meloni ${ }^{1,2}$, María José Nieva², Carlos Alberto Martínez ${ }^{3}$ \\ ${ }^{1}$ Universidad Nacional de Santiago del Estero, INDEAS, Facultad de Agronomía y Agroindustrias, Santiago \\ del Estero, Argentina - dmeloniunse@gmail.com \\ ${ }^{1}$ Universidad Nacional de Santiago del Estero, INSIMA, Facultad de Ciencias Forestales, Santiago del \\ Estero, Argentina - marijo_nieva@hotmail.com \\ ${ }^{3}$ Department of Biology, FFCLRP, University of São Paulo, Ribeirão Preto, São Paulo, Brazil - \\ carlosamhr@ffclrp.usp.br
}

\begin{abstract}
In recent decades, the phytogeographic region of the Western Chaco has been subjected to heavy deforestation. The native forest was gradually replaced by agricultural crops using high doses of herbicides. Glyphosate is the most widely used herbicide, and its impact on the surrounding native flora is unknown. The aim of this work was to determine the effect of glyphosate on the germination of Prosopis alba seeds and the photosynthesis of seedlings.

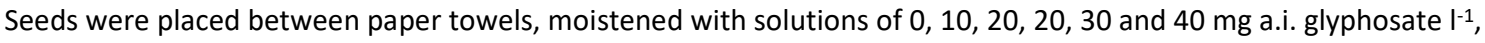
in a growth chamber at $25{ }^{\circ} \mathrm{C}$ and a $12 \mathrm{~h}$ photoperiod. The percentage of germinated seeds and the mean germination time were calculated. The respiratory rate was measured in these seeds, and the activity of complexes I and III of the respiratory chain was quantified. The shikimate concentration and antioxidant response of the seeds were also quantified. Chlorophyll fluorescence emission variables were measured in the cotyledons. It was concluded that glyphosate inhibits germination in $P$. alba seeds and decreases the speed of the process. This effect can partly be explained by inhibition of respiration, mainly at the level of complex III of the mitochondrial electron transport chain. It is also due to oxidative stress produced by the herbicide since the antioxidant response of the seeds fails to compensate for the high production of reactive oxygen species. Glyphosate inhibits the photochemical stage of photosynthesis on $P$. alba cotyledons.
\end{abstract}

KEYWORDS: Germination, Herbicides, Oxidative stress, Photosynthesis, Respiration.

\section{RESUMO}

Nas últimas décadas, a região fitogeográfica do Chaco Ocidental tem sofrido forte desmatamento. A floresta nativa foi substituída por lavouras agrícolas, com uso de altas doses de herbicidas. O glifosato é o herbicida mais utilizado, e o seu impacto na flora nativa circundante é desconhecido. O objetivo deste trabalho foi determinar o efeito do glifosato na germinação de sementes de Prosopis alba, e na fotossíntese das plântulas. As sementes foram colocadas entre toalhas de papel umedecidas com soluções de 0, 10, 20, 30 e $40 \mathrm{mg}$ i.a. glifosato $\mathrm{I}^{-1}$, em câmara de crescimento a $25^{\circ} \mathrm{C}$ e fotoperíodo de 12 horas. Foram calculados a porcentagem de sementes germinadas e o tempo médio de germinação. Nessas sementes foi medida a taxa respiratória e quantificadas as atividades dos complexos I e III da cadeia respiratória. Também foram quantificadas a concentração de chiquimato e a resposta antioxidante das sementes. Nos cotilédones foram medidas variáveis de emissão de fluorescência da clorofila a. Conclui-se que o glifosato inibe a germinação de sementes de $P$. alba e retarda este processo. Tal efeito pode ser explicado, em parte, pela inibição no nível do complexo III da cadeia de transporte de elétrons mitocondrial. Também se deve ao estresse oxidativo produzido pelo herbicida, uma vez que, a resposta antioxidante das sementes não pode compensar a alta produção de espécies reativas de oxigênio. $O$ glifosato inibe a etapa fotoquímica da fotossíntese nos cotilédones de $P$. alba.

PALAVRAS-CHAVE: Germinação, Herbicidas, Estresse oxidativo, Fotossíntese, Respiração. 


\section{INTRODUCTION}

In recent decades, the phytogeographic region of the Western Chaco has been subjected to heavy deforestation. Thus, a change in land use has been observed, and the native forest has been gradually replaced by agricultural crops (HOYOS et al., 2013). The sustained increase in the international price of commodities has accelerated this process and encouraged the cultivation of transgenic soybean (CÁCERES et al., 2015). The management of this crop includes the use of high doses of herbicides, mainly glyphosate (PIQUERRODRÍGUEZ et al., 2015).

Herbicides can be transported by wind towards the surrounding native forest, thus reaching non-target species. This phenomenon, known as drift, can lead to the death of sensitive species and jeopardize the biodiversity of these ecosystems (DUPONT et al., 2018).

Recently, FERREIRA et al. (2017) studied the effect of glyphosate on 23 herbaceous and shrub species native to the Western Chaco. Their results showed that a dose of $25 \%$ of the recommended field rate was lethal or sublethal for all of them $(50 \%$ of the species studied manifested severe toxicity and $75 \%$ showed reduced growth).

Algarrobo blanco (Prosopis alba) is a native tree species of the Western Chaco; its wood is highly valued for furniture production, and its fruits are consumed by wildlife and livestock (MELONI et al., 2019). The degree of tolerance of $P$. alba to glyphosate and the impact of this herbicide on germination and seedling development of this species are unknown.

Glyphosate acts by inhibiting the enzyme 5enolpyruvyl-shikimate-3-phosphate synthase (EPSPS), which is involved in the shikimic acid pathway. This metabolic process leads to the synthesis of aromatic amino acids (ALCÁNTARA DE LA CRUZ et al., 2016).

Germination is a critical stage for the establishment of seedlings in forest ecosystems. The effect of glyphosate on germination has been insufficiently studied, and the results obtained have been contradictory. GOMES et al. (2017a) demonstrated that glyphosate inhibits the germination of Dimorphandra wilsonii, a species native to the Brazilian Cerrado. On the other hand, glyphosate does not affect the percentage of maize germination, but decreases the speed of the process (GOMES et al., 2019a).

Glyphosate can affect the physiology of seedlings of forest species, inhibiting photosynthesis and altering ionic homeostasis and nitrogen metabolisms, among others (CARVALHO et al., 2018; GOMES et al., 2014). Glyphosate can also lead to the accumulation of reactive oxygen species (ROS). ROS are involved in the mobilization of seed reserves as well as in the signaling in response to environmental cues. At high concentrations, they can cause severe damage to metabolism (VERMA et al., 2015).

The aim of this work was to determine the effect of glyphosate on the germination of $P$. alba seeds and the photosynthesis of seedlings.

\section{MATERIAL AND METHODS}

\section{Seed collection area}

Prosopis alba fruits were harvested from randomly selected trees at the experimental station of the Instituto Nacional de Tecnología Agropecuaria, Santiago del Estero, Argentina (28은 3 ' 64 14' E). The experimental station has an area of approximately $6 \mathrm{~km}^{2}$ with different types of vegetation: native forest, grasslands and shrublands. It is located in the phytogeographic region of the Western Chaco and has a subtropical climate with a dry season. The average annual temperature is $26^{\circ} \mathrm{C}$, and the annual rainfall is $574 \mathrm{~mm}$ (IBÁÑEZ et al., 2021).

\section{Seed germination trials}

Seeds were manually extracted and selected by size and uniform color. They were then disinfected with $2.5 \%$ sodium hypochlorite for $10 \mathrm{~min}$, followed by three washes in sterile distilled water. To facilitate the imbibition of the seeds, a cut was made with pliers at the opposite end of each embryo. Four replications of 50 seeds were placed to germinate between paper towels moistened with $10 \mathrm{ml}$ of distilled water (control) or glyphosate solutions of 10, 20, 30 and $40 \mathrm{mg}$ a.i. $\mathrm{l}^{-1}$. The germination towels were rolled, covered with polyethylene bags to minimize water loss by evaporation and placed vertically in a growth chamber at $25{ }^{\circ} \mathrm{C}$ with a $12 \mathrm{~h}$ photoperiod. Seeds in which the cotyledons emerged were considered germinated. Germination percentage and mean germination time (MGT) were calculated according to NICHOLS \& HEIDECKER (1996).

\section{Respiration measurements and determinations of the activity of complexes I and III of the mitochondrial electron transport chain}

Respiration measurements were made $48 \mathrm{~h}$ after the treatments were initiated. A total of $1.5 \mathrm{~g}$ of seeds was placed in $5 \mathrm{ml}$ vials containing $8 \mathrm{ml}$ of $8 \mathrm{mM}$ HEPES buffer, 
$\mathrm{pH}$ 7.2. The $\mathrm{O}_{2}$ consumption was measured using a TBR1025 sensor (World Precision Instruments, Sarasota, Florida, USA). This sensor consists of silver and platinum electrodes. The measurements were performed following the methodology described by Pandey et al. (2019).

To determine the activity of complexes I and III of the mitochondrial electron transport chain, seeds were homogenized in $200 \mathrm{mM}$ potassium phosphate buffer, $\mathrm{pH}$ 7.5. The activities of complexes I (NADH: ubiquinone oxidoreductase) and III (ubiquinol-cytochrome c reductase) were determined spectrophotometrically according to the techniques described by Estornell et al. (1993) and Birch-Machin et al. (1993), respectively.

\section{Shikimate determinations and oxidative stress variables}

Seeds were arranged under the same conditions and treatments described in the germination assays.

Shikimate was quantified using the technique reported by Singh \& Shaner (1998), with some modifications. Seeds were homogenized with a pestle and mortar in $0.25 \mathrm{~N}$ $\mathrm{HCl}$. The homogenate was then centrifuged at $25,000 \mathrm{xg}$ and $5{ }^{\circ} \mathrm{C}$ for $20 \mathrm{~min}$. Aliquots of $40 \mu \mathrm{l}$ of the supernatant were collected, to which $500 \mu \mathrm{l}$ of $1 \%$ periodic acid solution was added. After incubation for $2 \mathrm{~h}, 500 \mu \mathrm{l}$ of $1 \mathrm{~N}$ $\mathrm{NaOH}$ solution and $300 \mu \mathrm{l}$ of $0.1 \mathrm{M}$ glycine were added. Vigorous mixing was done, and absorbance was read at $380 \mathrm{~nm}$. Concentrations were expressed in $\mu \mathrm{mol} \mathrm{g} \mathrm{g}^{-1} \mathrm{FW}$.

The $\mathrm{O}_{2}^{--}$concentration was quantified by nitrite formation from hydroxylamine in the presence of superoxide (ELSTNER \& HEUPEL, 1976). Results were expressed in $\mathrm{nmol} \mathrm{min}^{-1} \mathrm{~g}^{-1} \mathrm{FW}$.

The $\mathrm{H}_{2} \mathrm{O}_{2}$ concentration was determined by the technique described by ZHOU et al. (1997) using N-acetyl3, 7-dihydroxyphenoxazine (Amplex Red). The enzymatic oxidation of Amplex Red was quantified spectrophotometrically, reading absorbance at $560 \mathrm{~nm}$. Results were expressed as $\mu \mathrm{mol}_{2} \mathrm{O}_{2} \mathrm{~g}^{-1} \mathrm{FW}$.

Malondialdehyde was extracted with trichloroacetic acid and quantified spectrophotometrically according to the method reported by Heath \& Paker (1968). The concentration was calculated using an absorption coefficient of $155 \mathrm{mM}^{-1} \mathrm{~cm}^{-1}$. Results were expressed as $\mu \mathrm{mol} \mathrm{g} \mathrm{g}^{-1} \mathrm{FW}$.

To determine the enzymatic activities, seeds were homogenized in phosphate buffer, $\mathrm{pH}$ 7.0. The homogenate was centrifuged at $15,000 \mathrm{~g}$ and $5{ }^{\circ} \mathrm{C}$ for 20 minutes. The supernatant was used to determine protein concentration, according to the technique developed by Bradford (1976), and enzyme activities.
Ascorbate peroxidase activity (APX, EC 1.11.1.11) was determined by measuring ascorbate oxidation at $290 \mathrm{~nm}$, using the technique provided by Nakano \& Asada (1981). APX activity was expressed as $\mu \mathrm{mol}$ ascorbate $\mathrm{mg}^{-1}$ protein $\min ^{-1}$.

Catalase activity (CAT; EC 1.11.1.6) was determined through the oxidation of $\mathrm{H}_{2} \mathrm{O}_{2}$ at $240 \mathrm{~nm}$, using a molar extinction coefficient of $36 \mathrm{M}^{-1} \mathrm{~cm}^{-1}$, according to the technique described by HAVIR \& MCHALE (1987). The CAT activity was expressed as $\mu \mathrm{mol}_{2} \mathrm{O}_{2} \mathrm{mg}^{-1}$ protein ${ }^{-1} \mathrm{~min}^{-1}$.

The superoxide dismutase activity (SOD, EC 1.15.1.1) was determined according to the method used by Giannopolitis \& Ries (1977). For this purpose, the photoreduction inhibition of nitro blue tetrazolium chloride was quantified at $540 \mathrm{~nm}$. One unit of SOD consisted of the amount of enzyme required to inhibit by half the photoreduction of nitro blue tetrazolium chloride. SOD activity was expressed as $\mathrm{U} \mathrm{mg}^{-1}$ protein $\mathrm{min}^{-1}$.

\section{Chlorophyll a fluorescence emission measurement}

Chlorophyll fluorescence emission measurements were made on cotyledons of germinated seeds. Measurements were performed with a portable fluorometer (LI-6400-40; Li-Cor Inc.). The light-saturation pulse method was used in light-adapted cotyledons and 1 $h$ of darkness (SCHREIBER et al., 1994). Pulse intensity and duration were $8,000 \mu \mathrm{mol} \mathrm{m} \mathrm{m}^{-2} \mathrm{~s}^{-1}$ and $0.8 \mathrm{~s}$, respectively. The following variables were calculated: maximum PSII quantum efficiency $\left(F_{v} / F_{m}\right)$, photochemical quenching ( $q P$ ) and non-photochemical quenching (NPQ), according to the equations proposed by Genty et al. (1989), Kramer et al. (2004) and Bilger \& Björkman (1995), respectively.

\section{Experimental design and statistical analysis}

A completely randomized experimental design with four replicates was used. The experimental unit was represented by a germination towel with 50 seeds. Results were analyzed with ANOVA and Tukey's test.

\section{RESULTS AND DISCUSSION}

The germination of $P$. alba was inhibited from a dose of $30 \mathrm{mg}$ a.i. glyphosate $\mathrm{I}^{-1}$. The maximum inhibition was recorded at the dose of $40 \mathrm{mg}$ a.i. glyphosate $\mathrm{I}^{-1}$, with a reduction of $30 \%$ with respect to the control (Figure $1 \mathrm{~A}$ ). The speed of the process, measured through the MGT, was more sensitive than the final percentage of germinated seeds (Figure 1 B). As the dose was increased, 
germination was slower, with a concomitant increase in the MGT. Thus, while in the control the MGT was approximately 4 days, at the highest dose it approached to 9 days.

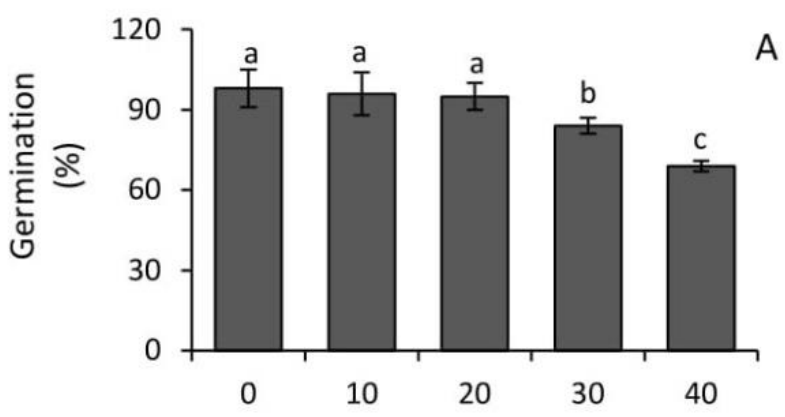

Glyphosate (mg a.i. $\left.\right|^{-1}$ )

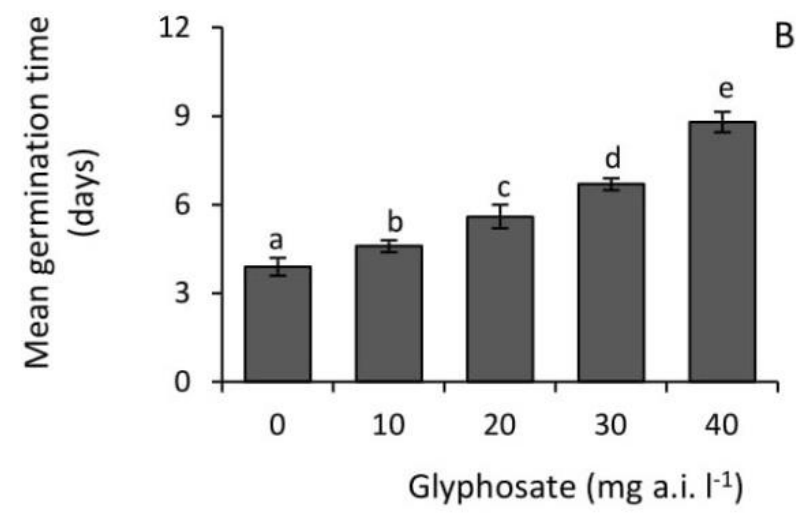

Figure 1. Germination (A) and mean germination time (B) in $P$. alba seeds treated with increasing doses of glyphosate. Different letters indicate significant differences by Tukey's test at $5 \%$.

Coinciding with the behavior observed in the MGT, all glyphosate doses increased the concentration of shikimate in $P$. alba seeds (Figure 2). This result indicates that doses of 10 to $40 \mathrm{mg}$ a.i. glyphosate $\mathrm{I}^{-1}$ inhibited the EPSPS enzyme. On the other hand, the increase in shikimate concentration is a typical response of glyphosate-sensitive species (SCHRÜBBERS et al., 2014).

To our knowledge, this is the first report on the effect of glyphosate on $P$. alba germination. For this reason, we investigated its effect on the respiratory metabolism. Respiration is a very important metabolic process during germination because it provides energy and carbon skeletons for biosynthetic pathways (GOMES et al., 2014).

As shikimate concentration in seeds increased, the respiration rate decreased (Figure $3 \mathrm{~A}$ ). Respiration in seeds treated with 10 and $40 \mathrm{mg}$ a.i. glyphosate $\mathrm{I}^{-1}$ decreased by $14 \%$ and $41 \%$ compared to the control, respectively.

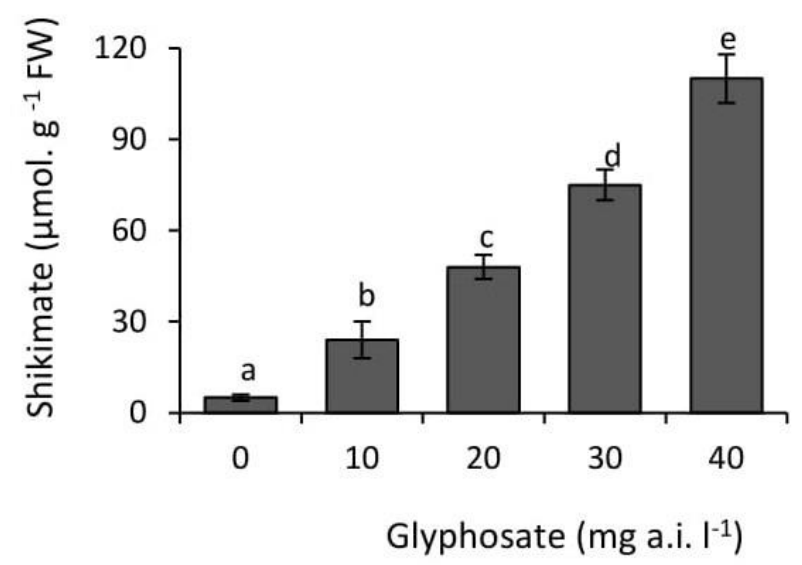

Figure 2. Concentration of shikimate in $P$. alba seeds treated with increasing doses of glyphosate. Different letters indicate significant differences by Tukey's test at $5 \%$.

Respiration consists of four stages: glycolysis, Krebs cycle, mitochondrial electron transport chain and oxidative phosphorylation. We studied the effect of glyphosate on the activity of protein complexes I and III in the mitochondrial electron transport chain. The activity of both complexes was inhibited by the herbicide, but the effect was more pronounced on complex III (Figures 3B and $3 C$ ). The activity of complex I was inhibited from 20 $\mathrm{mg}$ a.i. glyphosate $\mathrm{I}^{-1}$; at the dose of $40 \mathrm{mg}$ a.i. glyphosate $\mathrm{I}^{-1}$, its activity was $33 \%$ lower than in the control. In contrast to this response, the activity of complex III was inhibited from $10 \mathrm{mg}$ a.i. glyphosate $\mathrm{I}^{-1}$; at the dose of 40 $\mathrm{mg}$ a.i. glyphosate $\mathrm{I}^{-1}$, its activity was $62 \%$ lower than in the control.

Gomes et al. (2017a) reported similar results on seeds of Dimorphandra wilsonii, a leguminous tree species native to the Brazilian Cerrado. In that species, doses of 5 to $50 \mathrm{mg}$ a.i. glyphosate $\mathrm{l}^{-1}$ produced a drastic inhibition in germination. These authors also observed that glyphosate inhibited seed respiration, especially at the level of complex III activity. Similarly, doses of 24 to $100 \mathrm{mg}$ a.i. glyphosate $\mathrm{I}^{-1}$ produced a $30 \%$ reduction in sorghum germination. This effect was due to inhibition in the de novo synthesis of gibberellins and in the respiratory rate (GOMES et al., 2019b). 


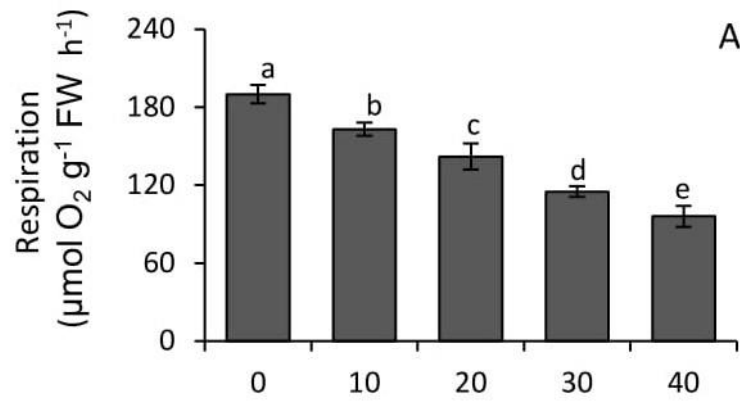

Glyohosate (mg a.i. $\left.\left.\right|^{-1}\right)$
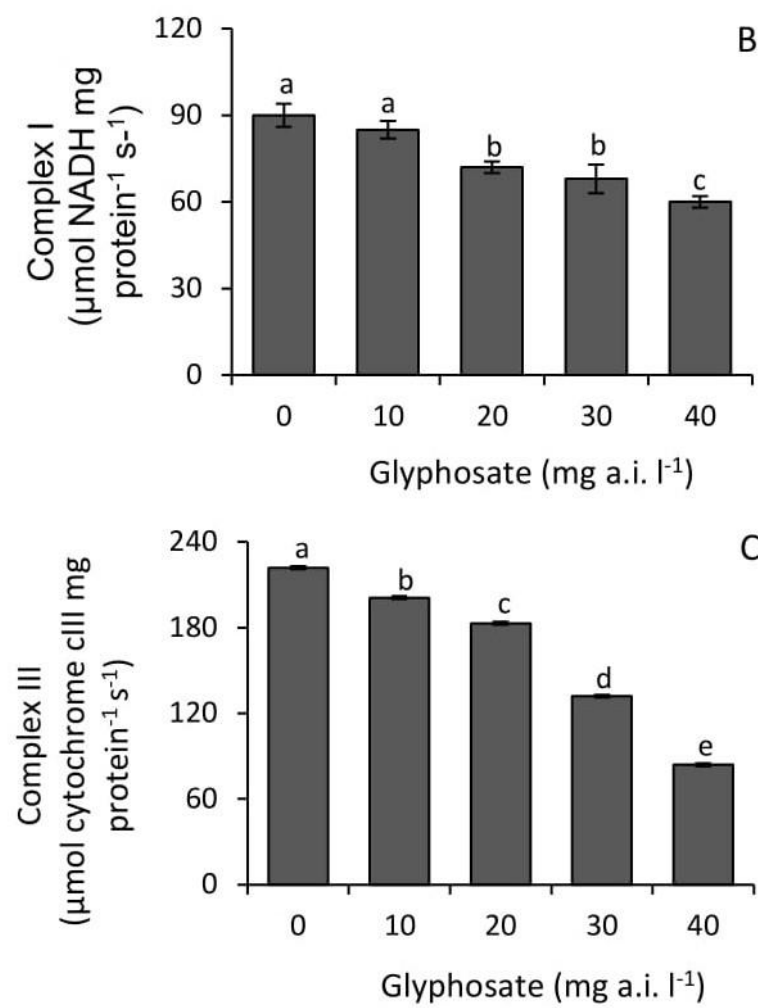

Figure 3. Respiratory rate $(A)$ and activities of complexes I (B) and III (C) of the mitochondrial electron transport chain in $P$. alba seeds treated with increasing doses of glyphosate. Different letters indicate significant differences by Tukey's test at $5 \%$.

In response to glyphosate, $P$. alba seeds increased the activity of enzymes involved in the ROS detoxification (Table 1). The APX activity increased from the dose of 30 $\mathrm{mg}$ a.i. glyphosate $\mathrm{I}^{-1}$, whereas the activities of CAT and SOD enzymes increased from $20 \mathrm{mg}$ a.i. glyphosate $\mathrm{I}^{-1}$.
Table 1. Activities of ascorbate peroxidase (APX, $\mu \mathrm{mol}$ ascorbate $\mathrm{mg}^{-1}$ protein $\mathrm{min}^{-1}$ ), catalase (CAT, $\mu \mathrm{mol} \mathrm{H}_{2} \mathrm{O}_{2} \mathrm{mg}^{-1}$ protein ${ }^{-1} \mathrm{~min}^{-1}$ ) and superoxide dismutase ( $\mathrm{SOD}, \mathrm{U} \mathrm{mg}^{-1}$ protein $\mathrm{min}^{-1}$ ) enzymes in P.alba seeds treated with increasing doses of glyphosate. Values represent means \pm SD of four replicates.

\begin{tabular}{cccc}
\hline $\begin{array}{c}\text { Glyphosate } \\
\text { (mg a.i. } \mathbf{~ I}^{-1} \text { ) }\end{array}$ & APX & CAT & SOD \\
\hline 0 & $0,18 \pm 0,02$ a & $31,2 \pm 1,30$ a & $1,21 \pm 0,09$ a \\
10 & $0,20 \pm 0,01$ a & $30,4 \pm 0,92$ a & $1,33 \pm 0,07$ a \\
20 & $0,17 \pm 0,03$ a & $36,7 \pm 2,57$ b & $2,84 \pm 0,14$ b \\
30 & $0,25 \pm 0,01 \mathrm{~b}$ & $41,0 \pm 1,45 \mathrm{c}$ & $3,98 \pm 0,11 \mathrm{c}$ \\
40 & $0,41 \pm 0,04 \mathrm{c}$ & $60,9 \pm 2,61 \mathrm{~d}$ & $5,17 \pm 0,23 \mathrm{~d}$ \\
\hline
\end{tabular}

Means followed by the same letter in the column do not differ statistically at $\mathrm{p}<0.05$ (Tukey's test).

Despite the increase in APX, CAT and SOD enzyme activities, glyphosate produced oxidative stress in $P$. alba seeds, increasing superoxide radical $\left(\mathrm{O}_{2}{ }^{-}\right)$and $\mathrm{H}_{2} \mathrm{O}_{2}$ concentrations (Table 2). Coinciding with the increase in ROS concentrations, there was a strong increase in the concentration of MDA (Table 2), the product of lipid peroxidation.

Table 2. Concentrations of superoxide radical $\left(\mathrm{O}_{2}{ }^{-}, \mathrm{nmol}\right.$ $\left.\min ^{-1} \mathrm{~g}^{-1} \mathrm{FW}\right)$, hydrogen peroxide $\left(\mathrm{H}_{2} \mathrm{O}_{2}, \mu \mathrm{mol} \mathrm{g}{ }^{-1}\right.$ FW) and malondialdehyde (MDA, $\mu \mathrm{mol} \mathrm{g}^{-1} \mathrm{FW}$ ) in $P$. alba seeds treated with increasing doses of glyphosate. Values represent the means \pm SD of four replicates.

\begin{tabular}{cccc}
\hline $\begin{array}{c}\text { Glyphosate } \\
\text { (mg a.i. } \mathbf{~}^{-1} \text { ) }\end{array}$ & $\mathbf{O}_{2}{ }^{--}$ & $\mathbf{H}_{2} \mathbf{O}_{2}$ & MDA \\
\hline 0 & $9,2 \pm 0,3 \mathrm{a}$ & $10,1 \pm 0,2 \mathrm{a}$ & $21,1 \pm 3,2 \mathrm{a}$ \\
10 & $17,5 \pm 0,5 \mathrm{~b}$ & $13,6 \pm 0,1 \mathrm{~b}$ & $32,9 \pm 2,5 \mathrm{~b}$ \\
20 & $24,1 \pm 0,1 \mathrm{c}$ & $15,9 \pm 0,9 \mathrm{c}$ & $45,4 \pm 4,9 \mathrm{c}$ \\
\hline 30 & $43,8 \pm 0,6 \mathrm{~d}$ & $23,5 \pm 0,7 \mathrm{~d}$ & $73,8 \pm 1.6 \mathrm{~d}$ \\
40 & $59,3 \pm 0,3 \mathrm{e}$ & $33,4 \pm 0,4 \mathrm{e}$ & $102,2 \pm 4,1 \mathrm{e}$ \\
\hline
\end{tabular}

Means followed by the same letter in the column do not differ statistically at $p<0.05$ (Tukey's test).

High ROS production can damage macromolecules such as proteins, lipids and DNA. At the cellular level, lipid peroxidation can alter the selective permeability of membranes, with loss of solutes (VIEIRA et al., 2019). However, ROS also increase protein carbonylation, which increases their proteolysis, leading to the mobilization of these reserves during germination (JOB et al., 2005). Therefore, at low concentrations, ROS are essential to promote the signaling processes necessary for germination. At high concentrations, ROS are detrimental 
since they can compromise membrane structure and biological functions.

Gomes et al. (2019a) reported that glyphosate decreased the germination rate in maize. This trend was accompanied by an increase in the activity of both ascorbate peroxidase and catalase antioxidant enzymes. According to these authors, such an increase in the antioxidant activity allowed maintaining constant ROS contractions, interfering with germination.

Gomes et al. (2017b) reported different germination responses of three soybean cultivars treated with glyphosate. The germination of cultivars BRS 284 and L $8307 \mathrm{RR}$ was inhibited by glyphosate due to a significant increase in $\mathrm{H}_{2} \mathrm{O}_{2}$ concentrations. The germination of cultivar AS 3810 IORO was resistant to the herbicide, coinciding with low $\mathrm{H}_{2} \mathrm{O}_{2}$ production. According to these authors, ROS production occurs at the level of complex III of the mitochondrial inner membrane. Thus, the greater the inhibition of the activity of this protein complex, the greater the production of ROS.

Glyphosate inhibited the photochemical stage of photosynthesis in $P$. alba cotyledons. The $F_{v} / F_{m}$ ratio decreased from the dose of $20 \mathrm{mg}$ a.i. glyphosate $\mathrm{I}^{-1}$ (Table 3). This ratio represents the maximum PSII quantum efficiency, that is, the maximum efficiency with which light is absorbed by PSII and used for quinone $A$ reduction. Under optimal growth conditions, it has a value close to 0.75; lower values indicate photoinhibition (LIMAMELO et al., 2019). Meloni \& Martinez (2021) also reported photoinhibition in Eucalyptus camaldulensis seedlings under simulated glyphosate drift. All glyphosate doses tested produced decreases in $\mathrm{qP}$ and $\mathrm{NPQ}$ values (Table 3).

Table 3. Maximum PSII quantum efficiency $\left(F_{v} / F_{m}\right)$, photochemical quenching ( $(\mathrm{PP})$ and nonphotochemical quenching (NPQ) in $P$. alba cotyledons from seeds germinated in the presence of increasing doses of glyphosate. Values represent the means $\pm S D$ of four replicates.

\begin{tabular}{cccc}
\hline $\begin{array}{c}\text { Glyphosate } \\
\text { (mg a.i. } \mathbf{~ I}^{-\mathbf{1}} \text { ) }\end{array}$ & $\mathbf{F v}_{\mathbf{v}} / \mathbf{F}_{\mathbf{m}}$ & $\mathbf{q P}$ & $\mathbf{N P Q}$ \\
\hline 0 & $0,74 \pm 0,09 \mathrm{a}$ & $0,81 \pm 0,03 \mathrm{a}$ & $3,22 \pm 0,17 \mathrm{a}$ \\
10 & $0,76 \pm 0,11 \mathrm{a}$ & $0,73 \pm 0,09 \mathrm{~b}$ & $2,68 \pm 0,21 \mathrm{~b}$ \\
20 & $0,65 \pm 0,06 \mathrm{~b}$ & $0,56 \pm 0,05 \mathrm{c}$ & $2,13 \pm 0,19 \mathrm{c}$ \\
30 & $0,52 \pm 0,03 \mathrm{c}$ & $0,48 \pm 0,02 \mathrm{~d}$ & $1,09 \pm 0,13 \mathrm{~d}$ \\
40 & $0,26 \pm 0,01 \mathrm{~d}$ & $0,27 \pm 0,01 \mathrm{e}$ & $0,62 \pm 0,18 \mathrm{e}$ \\
\hline
\end{tabular}

Means followed by the same letter in the column do not differ statistically at $p<0.05$ (Tukey's test).
The $\mathrm{qP}$ values represent the proportion of open reaction centers; therefore, a decrease in them indicates lower photochemical efficiency (LIMA NETO et al., 2019). $A$ decrease in NPQ values was also recorded. The increase in NPQ values constitutes a photoprotection mechanism, dissipating as heat the excess energy in the photochemical stage of photosynthesis. This dissipation occurs through the xanthophyll cycle and tends to prevent photoinhibition. The decrease in NPQ values shows a deficient dissipation of excess energy as heat, which could be given by a lower concentration of carotenoids (VIEIRA et al., 2019).

The analysis of the behavior of fluorescence emission variables allows inferring that $10 \mathrm{mg}$ a.i. glyphosate $\mathrm{I}^{-1}$ produced a dynamic photoinhibition. This is because a decrease in $\mathrm{qP}$ was recorded, while the $\mathrm{Fv}_{\mathrm{v}} / \mathrm{Fm}_{\mathrm{m}}$ ratio remained constant. From $20 \mathrm{mg}$ a.i. glyphosate $\mathrm{I}^{-1}$, the herbicide produced chronic photoinhibition, which is usually associated with damage to the $D_{1}$ protein of photosystem II (LIMA-MELO et al., 2019).

Freitas-Silva et al. (2020) studied the effect of glyphosate on the physiology of two neotropical species native to Brazil, Handroanthus chysotricus (very sensitive to herbicide) and Garcinia gardneriana (moderately sensitive to herbicide). Doses from 360 to $1440 \mathrm{~g}$ a.i. ha ${ }^{-1}$ inhibited net photosynthesis of $H$. chysotricus, with significant decreases in the relation $\mathrm{Fv}_{\mathrm{v}} / \mathrm{F}_{\mathrm{m}}, \mathrm{qP}$ and NPQ. In G. gardneriana, glyphosate did not affect net photosynthesis or chlorophyll a fluorescence variable. In Pouteria torta, doses greater than or equal to $25 \mathrm{~g}$ a.i. ha ${ }^{-1}$ of glyphosate reduced net photosynthesis and produced photoinhibition, which was manifested by a decrease in the $F_{v} / F_{m}$ ratio. They also observed increased NPQ and a decrease in chlorophyll $a$ and $b$ concentrations (BATISTA et al., 2018).

\section{CONCLUSIONS}

It is concluded that glyphosate inhibits germination in $P$. alba seeds and decreases the speed of the process. This effect can be partly explained through the inhibition of respiration, mainly at the level of complex III of the mitochondrial electron transport chain. It is also due to oxidative stress produced by the herbicide since the antioxidant response of the seeds fails to compensate for the high production of ROS. Glyphosate inhibits the photochemical stage of photosynthesis in $P$. alba cotyledons. 


\section{REFERENCES}

ALCÁNTARA DE LA CRUZ, R. et al. Physiological, morphological and biochemical studies of glyphosate tolerance in Mexican Cologania (Cologania broussonetii (Balb.) DC.). Plant Physiology and Biochemistry, v.98, p.72-80, 2016.

BATISTA, P.F. et al. Pouteria torta: a native species of the Brazilian Cerrado as a bioindicator of glyphosate action. Brazilian Journal of Biology, v.78, n.2, p.296-305, 2018.

BILGER, W. et al. Determination of the quantum efficiency of photosystem II and of non-photochemical quenching of chlorophyll fluorescence in the field. Oecologia, v.102, n.4, p.425-432, 1995.

BIRCH-MACHIN, $M$. et al. Identification of mitochondrial dysfunction at coupling site II. Methods in Toxicology. Academic Press, p. 324-328, 1993.

BRADFORD, M.M. A rapid and sensitive method for the quantitation of microgram quantities of protein utilizing the principle of protein-dye binding. Analytical Biochemistry, v.72, n.1-2, p.248-254, 1976.

CÁCERES, D.M. Accumulation by dispossession and socioenvironmental conflicts caused by the expansion of agribusiness in Argentina. Journal of Agrarian Change, v.15, n.1, p.116-147, 2015.

CARVALHO, L.B. et al. Physiological responses of Eucalyptus $x$ urograndis to glyphosate are dependent on the genotype. Scientia Forestalis, v.46, n.118, p.177-187, 2018.

DUPONT, Y.L. et al. Effects of herbicide and nitrogen fertilizer on non-target plant reproduction and indirect effects on pollination in Tanacetum vulgare (Asteraceae). Agriculture, Ecosystems \& Environment, v.262, n.76-82, 2018.

ELSTNER, R.; HEUPEL, A. Inhibition of nitrite formation from hydroxylammonium chloride: a simple assay for superoxide dismutase. Analytical Biochemistry, v.70, n.2, p.616-620, 1976.

ESTORNELL, E. et al. Assay conditions for the mitochondrial NADH: coenzyme $Q$ oxidoreductase. Federation of European Biochemical Societies, v.332, n.1-2, p.127-131, 1993.

FERREIRA, M.F. et al. Effects of the herbicide glyphosate on nontarget plant native species from Chaco Forest (Argentina). Ecotoxicology and Environmental Safety, v.144, p.360-368, 2017.

FREITAS-SILVA, L. et al. Evaluation of morphological and metabolic responses to glyphosate exposure in two neotropical plant species, Ecological Indicators, v.113, e2020.106246, 2020.

GENTY, B. et al. The relationship between the quantum yield of photosynthetic electron transport and quenching of chlorophyll fluorescence. Biochimica et Biophysica Acta, v.990, n.1, p.87-92, 1989.
GIANNOPOLITIS, N.; RIES, S.K. Superoxide dismutase. I. Occurrence in higher plants. Plant Physiology, v.59, n.2, p.309314, 1977.

GOMES, M.P. et al. Alteration of plant physiology by glyphosate and its by-product aminomethylphosphonic acid (AMPA), an overview. Journal of Experimental Botany, v.65, n.67, p.46914703, 2014.

GOMES, M.P. et al. Effects of glyphosate acid and the glyphosate-commercial formulation (Roundup) on Dimorphandra wilsonii seed germination: Interference of seed respiratory metabolism. Environmental Pollution, v.220, p.452459, 2017a.

GOMES, M.P. et al. Glyphosate can decrease germination of glyphosate-resistant soybeans. Journal of Agricultural and Food Chemistry, v.65, n.11, p.2279-2286, 2017b.

GOMES, M.P. et al. Effects of Ciprofloxacin and Roundup on seed germination and root development of maize. Science of the Total Environment, v.651, p.2671-2678, 2019a.

GOMES, M.P et al. Does integrative effects of glyphosate, gibberellin and hydrogen peroxide ameliorate the deleterious effects of the herbicide on sorghum seed through its germination? Chemosphere, v.233, p.905-912, $2019 \mathrm{~b}$.

HAVIR, E.A.; MCHALE, N.A. Biochemical and developmental characterization of multiple forms of catalase in tobacco leaves. Plant Physiology, v.84, n.2, p.450-455, 1987.

HOYOS, L.E. et al. Deforestation and precipitation patterns in the arid Chaco forests of central Argentina. Applied Vegetation Science, v.16, n.2, p.260-271, 2013.

HEATH, R.L.; PACKER, L. Photoperoxidation in isolated chloroplasts. I. Kinects and stoichiometry of fatty acid peroxidation. Archives of Biochemistry and Biophysics, v.125, n.1, p.189-198, 1968.

IBÁÑEZ, A.V. et al. Heat shock effects on germination and seed survival of five woody species from the Chaco region, Flora, v.275, e2020.151751, 2021.

JOB, C. et al. Patterns of protein oxidation in Arabidopsis seeds and during germination. Plant Physiology, v.138, p.790-802, 2005.

KRAMER, D.M. et al. New fluorescence parameters for the determination of QA redox state and excitation energy fluxes. Photosynthesis Research, v.79, n.2, p.209-218, 2004.

LIMA-MELO, Y. et al. Photoinhibition of Photosystem I Provides Oxidative Protection During Imbalanced Photosynthetic Electron Transport in Arabidopsis thaliana. Frontiers in Plant Science, v.10, e2019.00916, 2019.

MELONI, D.A. et al. Effects of salt stress on germination, seedling growth, osmotic adjustment, and chlorophyll fluorescence in Prosopis alba G. Revista de la Facultad de Ciencias Agrarias UNCuyo, v.51, n.1, p.69-78, 2019. 
MELONI, D.A.; MARTíNEZ, C.A. Physiological responses of Eucalyptus camaldulensis (Dehnh.) to simulated glyphosate drift. Biofix Scientific Journal, v.6, n.1, p.46-53, 2021.

NAKANO, Y.; ASADA, K. Hydrogen peroxide is scavenged by ascorbate-specific peroxidase in spinach chloroplasts. Plant Cell Physiology, v.22, n.5, p.867-880, 1981.

NICHOLS, M.A.; HEIDECKER, W. Two approaches to the study of germination data. Proceeding of International Seed Testing Association, v.33, p.351-340, 1996.

PANDEY, $S$. et al. Nitric oxide accelerates germination via the regulation of respiration in chickpea, Journal of Experimental Botany, v.70, n.17, p.4539-4555, 2019.

PIQUER-RODRÍGUEZ, M. et al. Effects of past and future land conversions on forest connectivity in the Argentine Chaco. Landscape Ecology, v.30, p.817-833, 2015.

SCHREIBER, U. et al. Chlorophyll fluorescence as a nonintrusive indicator for rapid assessment of in vivo photosynthesis. Ecophysiology of photosynthesis, p.49-70, 1994.

SCHRÜBBERS, L.C. et al. Glyphosate spray drift in Coffea arabica - sensitivity of coffee plants and possible use of shikimic acid as a biomarker for glyphosate exposure. Pesticide Biochemistry Physiology, v.115, p.15-22, 2014.

SINGH, B.; SHANER, D. Rapid determination of glyphosate injury to plants and identification of glyphosate-resistant plants. Weed Technology, v.12, n.3, p.527-530, 1998.

VERMA, G. et al. Reactive oxygen species mediate axis-cotyledon signaling to induce reserve mobilization during germination and seedling establishment in Vigna radiate. Journal of Plant Physiology, v.184, p.79-88, 2015.

VIEIRA, C.F. et al. Integrative approach reveals new insights into photosynthetic and redox protection in ex vitro tobacco plantlets acclimatization to increasing light intensity. Biotechnology Research and Innovation, v.3, n.1, p.59-72, 2019.

ZHOU, M. et al. A stable nonfluorescent derivative of resorufin for the fluorometric determination of trace hydrogen peroxide: applications in detecting the activity of phagocyte NADPH oxidase and other oxidases. Analytical Biochemistry, v.253, n.2, p.162-168, 1997. 